\title{
Expression and localisation of oestrogen and progesterone receptors in the bovine mammary gland during development, function and involution
}

\author{
D Schams, S Kohlenberg, W Amselgruber ${ }^{1}$, B Berisha, M W Pfaffl \\ and $\mathbf{F}$ Sinowatz ${ }^{2}$ \\ Institute of Physiology, Technical University Munich-Weihenstephan, D-85350 Freising, Germany \\ ${ }^{1}$ Department of Anatomy and Physiology, University Hohenheim, D-70593 Stuttgart, Germany \\ ${ }^{2}$ Department of Animal Anatomy II, Ludwig-Maximilians-University Munich, D-80539 Munich, Germany \\ (Requests for offprints should be addressed to D Schams; Email: physio@wzw.tum.de)
}

\begin{abstract}
It is now well established that oestrogen and progesterone are absolutely essential for mammary gland development. Lactation can be induced in non-pregnant animals by sex steroid hormone treatment. Most of the genomic actions of oestrogens are mediated by two oestrogen receptors (ER) $-\alpha$ and $E R \beta$, and for gestagens in ruminants by the progesterone receptor (PR). Our aim was the evaluation of mRNA expression and protein (localisation and Western blotting) during mammogenesis, lactogenesis, galactopoiesis (early, middle and late) and involution $(8,24,28$, 96-108 $\mathrm{h}$ and 14-28 days after the end of milking) in the bovine mammary gland (total no. 53). During these stages, the mRNA was assessed by means of real-time RT-PCR (LightCycler). The protein for ER $\alpha, \operatorname{ER} \beta$ and PR was localised by immunohistochemistry and Western blotting. The mRNA expression results indicated the existence of $\mathrm{ER} \alpha, \mathrm{ER} \beta$ and PR in bovine mammary gland. Both ER $\alpha$ and $P R$ are expressed in $\mathrm{fg} / \mu \mathrm{g}$ total RNA range. The highest mRNA expression was found for ER $\alpha$ and PR in the tissue of non-pregnant heifers, followed by a significant decrease to a lower level at the time of lactogenesis with low concentrations remaining during lactation and the first 4 weeks of involution. In contrast, the expression of ER $\beta$ was about 1000-fold lower (ag/ $\mu$ g total RNA) and showed no clear difference during the stages examined, with a significant increase only $2-4$ weeks after the end of milk-
\end{abstract}

ing. Immunolocalisation for ER $\alpha$ revealed a strong positive staining in nuclei of lactocytes in non-pregnant heifers, became undetectable during pregnancy, lactogenesis and lactation, and was again detectable 14-28 days after the end of milking. In contrast, PR was localised in the nuclei of epithelial cells in the mammary tissue of non-pregnant heifers, in primigravid animals, and during late lactation and involution. During lactogenesis, peak and mid lactation, fewer nuclei of epithelial cells were positive, but increased staining of the cytoplasm of epithelial cells was obvious. ER $\alpha$ and $\operatorname{ER} \beta$ protein was found in all mammary gland stages examined by Western blotting. In contrast to mRNA expression, the protein signal for ER $\alpha$ was weaker in the tissue of non-pregnant heifers and during involution (4 weeks). ER $\beta$ protein showed a stronger signal (two isoform bands) in non-pregnant heifers and 4 weeks after the end of milking. This correlated with the mRNA expression data. Three isoforms of PR (A, B and C) were found by Western blotting in the tissue of non-pregnant heifers, but only isoform B remained during the following stages (lactogenesis, galactopoiesis and involution). In conclusion, the mRNA expression and protein data for ER and PR showed clear regulatory changes, suggesting involvement of these receptors in bovine mammary gland development and involution.

Journal of Endocrinology (2003) 177, 305-317

\section{Introduction}

It is now well established that oestrogen and progesterone are absolutely essential for mammary epithelial proliferation and differentiation (Cowie et al. 1980, Topper \& Freeman 1980, Daniel \& Silberstein 1987). Our current understanding of the developmental biology of mammary glands is mostly derived from studies using mice and rats.
Oestrogen stimulates the development of mammary ducts, and progesterone and oestrogen stimulate the development of alveolar tissues. Artificial induction of lactation in non-pregnant animals has been attempted in the cow (Erb 1977). There is no evidence that mammogenic hormones (bovine somatotrophin, prolactin or placental lactogen) directly stimulate bovine mammary epithelial cells in vitro (Collier et al. 1993). In contrast, in vivo, combined 
treatment with oestradiol and progesterone induces physiological development of the lobulo-alveolar structure of the mammary gland in the presence of prolactin in sheep (Schams et al. 1984) or lactation in heifers (Schams 1976). In order to better understand the involvement of oestrogen and progesterone for normal development and during the function of the mammary gland, it is necessary to determine the distribution and expression pattern of oestrogen receptors (ER) and progesterone receptors (PR).

Most of the genomic actions of oestrogens are mediated by two ERs (ER $\alpha$ and ER $\beta$ ). In their DNA-binding domains, ER $\alpha$ and ER $\beta$ share $96 \%$ homology and recognise the same oestrogen-responsive element on genomic DNA. In their ligand-binding domains, there is only $60 \%$ homology, and this results in some degree of ligand selectivity between the receptors. As shown for the rat, both ER $\alpha$ and $\operatorname{ER} \beta$ activate transcription, they can work in opposite directions and activate protein-1 response elements. In general, $\mathrm{ER} \alpha$ is an activator, but $\operatorname{ER} \beta$ is an inhibitor or without effects at activating protein-1 sites (Saji et al. 2001).

The PR is composed of two protein isoforms, termed A and $\mathrm{B}$. Both isoforms are expressed from a single gene in rodents and humans. The selective physiologic roles of the two isoforms of $\mathrm{PR}$ are unknown. The ratio of A to B forms is 3:1 in the murine species (Schneider et al. 1991). In vitro studies in the human have shown that the $\mathrm{A}$ and $\mathrm{B}$ forms can have different functions in the same cell and also that the activity of the individual form of the receptor can vary among different cell types (Vegeto et al. 1993). Comparable isoforms have not yet been described for large domestic animals. The binding of progesterone to the PR causes the displacement of heat shock proteins, which allows stable receptor dimer formation. The dimers then bind the hormone response element, resulting in interactions with transcriptional mediators that repress or activate transcription. PR expression is under the control of oestrogen. Oestrogen increases PR expression and progesterone decreases PR expression (for reviews see Conneely et al. 2000, Peterson 2000).

The aim of the present paper was to study mRNA expression of ER $\alpha, E R \beta$ and PR by real-time PCR and protein by localisation of ER and PR by immunohistochemistry or Western blotting in the bovine mammary gland during different stages of development, function and involution. The results may help to improve our understanding of the possible role of steroid receptors regulating mammary gland function.

\section{Materials and Methods}

\section{Animals, tissue sampling and preparation}

The mammary glands from German Fleckvieh and Holstein Frisian cows (23 in total) were removed within $20 \mathrm{~min}$ of slaughter during defined stages. Small pieces
(1-2 g) of mammary tissue and liver were frozen in liquid nitrogen and stored at $-80{ }^{\circ} \mathrm{C}$. Slices of the mammary tissue were prepared for immunohistochemistry as described later. The classification of the animals was established as follows. (i) Ductal growth (18-month-old non-pregnant heifers, $n=4$ ); lobulo-alveolar development during first pregnancy (only for immunohistochemistry); (ii) days 194-213 of pregnancy $(n=4)$; (iii) days $252-272$ of pregnancy $(n=4)$; (iv) lactogenesis (onset of secretion during days $4-8$ post partum, $n=4$ ); galactopoiesis; (v) peak lactation (2-8 weeks post partum, $n=5)$; (vi) mid lactation (4-5 months, $n=4)$; (vii) late lactation (8-12 months, $n=4)$; involution (after the end of milking): (viii) $8 \mathrm{~h}(n=4)$; (ix) $24 \mathrm{~h}(n=4) ;(\mathrm{x}) 48 \mathrm{~h}(n=4)$; (xi) 96-108 h $(n=4)$; (xii) $14-28$ days $(n=6)$, and 2.5 years $(n=1$, only for immunohistochemistry).

\section{Immunohistochemistry}

For histology and immunohistochemistry, tissue samples (approximately $5 \mathrm{~mm}$ thick) were fixed in Bouin's solution for $48 \mathrm{~h}$ or in methanol/glacial acid $(2 / 1, \mathrm{v} / \mathrm{v})$, dehydrated in a graded series of ethanol, cleared in xylene and embedded in paraffin. Serial sections $(5 \mu \mathrm{m})$ were cut on a Leitz microtome and mounted on gelatine/chrom alum-coated glass slides.

Following deparaffinisation, the presence of ER $\alpha$ and PR was demonstrated immunohistochemically by the streptavidin-biotin-horseradish peroxidase complex (ABC) technique (Hsu et al. 1981). To expose antigenic sites for $\mathrm{ER} / \mathrm{PR}$, dewaxed sections were heated four times to $95^{\circ} \mathrm{C}$ in a $600 \mathrm{~W}$ microwave oven maintained for $5 \mathrm{~min}$ and allowed to cool for $20 \mathrm{~min}$. Endogenous peroxidase activity was then eliminated by incubation with $0.5 \%(\mathrm{v} / \mathrm{v})$ hydrogen peroxide solution in absolute methanol for 15 min at $20^{\circ} \mathrm{C}$. Non-specific protein binding was eliminated by incubation with $10 \%$ normal goat serum in phosphate-buffered saline (PBS) for $1 \mathrm{~h}$ at $20^{\circ} \mathrm{C}$. Sections were then incubated with a monoclonal antibody (1D5; Coulter Immunotech Company, Marseille, France) against $\mathrm{ER} \alpha$ or against PR (PR10A9; Coulter Immunotech) at a dilution of $1: 100$ for $18 \mathrm{~h}$ at $4{ }^{\circ} \mathrm{C}$. Incubation for $1 \mathrm{~h}$ with biotinylated rabbit anti-mouse $\operatorname{IgG}, 1: 400$ (AmershamPharmacia, Freiburg, Germany) followed. The sections were then reacted with $\mathrm{ABC}$ reagent from a commercial kit (Vector Laboratories, Burlingame, CA, USA). The bound complex was made visible by reaction with $0 \cdot 05 \%$ $3,3^{\prime}$ diaminobenzidine hydrochloride and $0.0006 \%$ hydrogen peroxide in $0 \cdot 1 \mathrm{M}$ PBS. Between each step, sections were washed three times in PBS and once in PBS 1\% bovine serum albumin (BSA). All incubations were carried out in humidified chambers to prevent evaporation. Sections were counterstained in Mayer's haematoxylin, dehydrated, cleared and mounted.

Controls were performed by: (i) replacing the primary antibody with non-immune serum, (ii) their substitution 
with buffer, (iii) replacing the secondary antibody with buffer and (iv) incubation with diaminobenzidine reagent alone to exclude the possibility of non-suppressed endogenous peroxidase activity. Lack of detectable staining (Fig. 2f) of tissue elements in the controls (Fig. 2e) (bovine uterine tissue served as a positive control) demonstrated the specificity of the reactions.

\section{Western blot}

Tissue extraction One gram of mammary tissue was transferred into five volumes of PBS containing one complete mini tablet of BSA (Boehringer, Mannheim, Germany). This tablet contains both reversible and irreversible protease inhibitors, and inhibits a broad spectrum of serine, cysteine, and metallo proteases. The mixture was homogenised in an ice bath with Ultra Turrax equipment (Jahnke and Kunkel, Staufen, Germany). The tissue was homogenised for $1 \mathrm{~min}$ and kept in ice water for $1 \mathrm{~h}$. Afterwards, SDS was added to a final concentration of $5 \%$ and the samples were boiled for $10 \mathrm{~min}$. After centrifugation for $10 \mathrm{~min}$ at $3500 \mathrm{~g}$ the protein content in the supernatant was determined.

Western blotting This was carried out according to Schuler et al. (2002) with modifications. Samples (50 $\mu \mathrm{g}$ protein in $20 \mu \mathrm{l}$ buffer) were boiled in $3 \times$ loading buffer (10 mM Tris-HCl, pH 6.8 including 3\% SDS, 5\% $\beta$-mercaptoethanol, $20 \%$ glycerol and $0.6 \%$ bromophenol blue for $3 \mathrm{~min}$ and separated on a commercially available 4-12\% Bis-Tris gel (Invitrogen, Karlsruhe LMA, Germany) under reducing conditions (for $1 \mathrm{~h}$ at $190 \mathrm{~V}$ ), and transferred to nitrocellulose membranes (Millipore PVDF, $0.45 \mu \mathrm{m}$; Millipore, Bedford, USA). For blocking, membranes were incubated in PBS with $0.05 \%$ Tween-20 (PBS-T) with $1 \%$ non-fat dry milk overnight. The membranes were then incubated in PBS-T and incubated for $75 \mathrm{~min}$ with the respective primary antibody: for PR a mouse monoclonal antibody (dilution 1:50), clone PRI0A9 (Coulter Immunotech Company), for ER $\alpha$ a rabbit polyclonal IgG (dilution 1:200) against epitope corresponding to amino acids $2-185$ mapping at the amino terminus of human ER $\alpha$ (no. sc 7207; Santa Cruz Biotech, Heidelberg, Germany) and for ER $\beta$ an N-terminal antirat polyclonal ER $\beta$ antibody (no. PA1-311; Affinity BioReagents, Golden, CO, USA) generated in rabbits against a peptide from amino acids 119-134 of the rat ER $\beta$ (dilution 1:750). This antibody was found to be useful for the bovine ovary (Rosenfeld et al. 1999). After washing in PBS-T, the membranes were incubated with the horseradish peroxidase-linked secondary goat anti-mouse or goat anti-rabbit immunoglobulin antibody (no. sc 7207; Santa Cruz Biotech) for $45 \mathrm{~min}$. At the end, they were again washed in PBS- $T$, incubated in enhanced chemiluminescence reagents (ECL Western blotting analysis system; Amersham-Pharmacia) for $30 \mathrm{~s}$ or $1 \mathrm{~min}$, and exposed to VA 711 B Blue Sensitive X-ray films.

Negative controls were set up replacing the primary monoclonal antibody with PBS. As a positive control sample, protein from bovine endometrium, corpus luteum extract or cell line lysate (MCF7, mammary adenocarcinoma, no. 2206; Santa Cruz) was used. For ER $\alpha$ band identification, cross-reaction study of PR and ER $\beta$ and for blocking of ER $\alpha$ antibody, a recombinant human ER $\alpha$ protein (Sigma, Munich, Germany) was used. See Blue Plus 2 Pre-Stained standard (Novex, San Diego, CA, USA) was used as molecular size marker.

\section{Total RNA extraction}

Total RNA was isolated from bovine tissues using an adapted guanidinium thiocyanate/phenol method as described (Plath et al. 1997). In the following steps, the Tripure protocol (Roche Diagnostics, Mannheim, Germany) with phenol/chloroform extraction for total RNA was used. In order to quantify the amount of total RNA extracted, the optical density was determined with a photometer (Eppendorf, Hamburg, Germany) at three different dilutions of the final RNA preparations at $260 \mathrm{~nm}$, corrected by the $320 \mathrm{~nm}$ background absorption. RNA integrity was electrophoretically verified by ethidium bromide staining and by $\mathrm{OD}_{260} / \mathrm{OD}_{280} \mathrm{~nm}$ absorption ratio $>1 \cdot 85$.

\section{Specific primer design}

The primers of the investigated transcripts (Table 1) were derived from the bovine and ovine sequences for ER $\alpha$ (EMBL accession nos AF110402; Y18017), ER $\beta$ (Z49257; AF177936) and PR (Z86041; Z66555). Primer pairs were designed to produce an ER $\alpha$ (234 bp), ER $\beta$ (262 bp) and PR (227 bp) amplification product spanning two RNA-splicing sites in the region of the receptor ligand-binding domain. PR primers are located near the $5^{\prime}$ end of mRNA and therefore cover both receptor isoforms A and B. Primer design and optimisation was done in the high homology regions of the multiple alignments with regard to primer dimer formation, self priming formation and primer melting temperature (HUSAR software at the German Research Centre, Heidelberg, Germany).

Primer sequences were additionally designed as multispecies primers (Table 1 ) which fit to the following species with high precision (>90\%): cattle (Bos taurus), sheep (Ovis aries), human (Homo sapiens), pig (Sus scrofa), mouse (Mus musculus) and rat (Rattus norwegicus).

\section{Reverse transcription (RT)}

Two micrograms of total RNA from the sample preparation were reverse transcribed in $40 \mu \mathrm{l}$ as follows: M-MLV RT buffer (Promega, Mannheim, Germany) and 
Table 1 Primer sequences of $E R \alpha, E R \beta, P R$, ubiquitin and resulting fragment size

\begin{tabular}{|c|c|c|c|}
\hline & Sequence of nucleotide* & $\begin{array}{l}\text { Fragment } \\
\text { size }(b p)\end{array}$ & EMBL reference ${ }^{* *}$ \\
\hline \multicolumn{4}{|l|}{ Target } \\
\hline \multirow[t]{2}{*}{$\mathrm{ER} \alpha$} & For 5'-AGG GAA GCT ССТ ATT TGC TCC-3' & 234 & Pfaffl et al. 2001 \\
\hline & Rev 5'-CGG TGG ATG TGG TCC TTC TCT-3' & & \\
\hline \multirow[t]{2}{*}{ ER $\beta$} & For 5'-GCT TCG TGG AGC TCA GCC TG-3' & 262 & Pfaffl et al. 2001 \\
\hline & Rev 5'-AGG ATC ATG GCC TTG ACA CAG A-3' & & \\
\hline \multirow[t]{2}{*}{ PR } & For 5'-GAG AGC TCA TCA AGG CAA TTG G-3' & 227 & Pfaffl et al. 2002 \\
\hline & Rev 5'-CAC CAT CCC TGC CAA TAT CTT G-3' & & \\
\hline Ubiquitin & For 5'-AGA TCC AGG ATA AGG AAG GCA T-3' & $198,426,654$ & Z18245; AF038129 \\
\hline
\end{tabular}

*For, forwards; Rev, reverse.

**EMBL accession number or reference of published sequence.

Table 2 Characteristics and validation parameters of real-time RT-PCR assays. Intra-assay and interassay variation of real-time RT-PCR assays were determined over the complete quantification range. Detection limit, quantification limit and variations were based on concentrations per capillary

\begin{tabular}{|c|c|c|c|}
\hline & $E R \alpha$ & ERß & PR \\
\hline Product length & 234 bp & $262 b p$ & $227 \mathrm{bp}$ \\
\hline Detection limit & 5 ag & 7 ag & $30 \mathrm{ag}$ \\
\hline Quantification limit & $404 \mathrm{ag}$ & $24 \mathrm{ag}$ & $1.7 \mathrm{fg}$ \\
\hline $\begin{array}{l}\text { Quantification range } \\
\text { (test linearity) }\end{array}$ & $\begin{array}{l}404 \mathrm{ag}-4.40 \mathrm{ng} \\
(r=0.995)\end{array}$ & $\begin{array}{l}24 \mathrm{ag}-24 \cdot 4 \mathrm{ng} \\
(\mathrm{r}=0.996)\end{array}$ & $\begin{array}{l}1 \cdot 7 \mathrm{fg}-17 \mathrm{ng} \\
(r=0.998)\end{array}$ \\
\hline PCR efficiency & $1 \cdot 81$ & $1 \cdot 82$ & 1.94 \\
\hline Intra-assay variation & $18 \cdot 7 \%(n=4)$ & $17 \cdot 6 \%(n=4)$ & $5 \cdot 7 \%(n=4)$ \\
\hline Interassay variation & $28 \cdot 6 \%(n=4)$ & $29 \cdot 7 \%(n=4)$ & $25 \cdot 7 \%(n=4)$ \\
\hline
\end{tabular}

$300 \mu \mathrm{M}$ dNTPs (MBI Fermentas, Vilnius, Lithuania) were denaturated for $5 \mathrm{~min}$ at $65^{\circ} \mathrm{C}$ in a MasterCycler gradient (Eppendorf). The subsequent RT was done at $37^{\circ} \mathrm{C}$ for $60 \mathrm{~min}$ by adding $2.5 \mathrm{mM}$ random hexamer primers (Pharmacia, Uppsala, Sweden), 200 U M-MLV RT (Promega) and 12.5 U RNAs in RNase inhibitor (MBI Fermentas). The samples were then heated for $1 \mathrm{~min}$ at $99^{\circ} \mathrm{C}$ to terminate $\mathrm{RT}$.

\section{Confirmation of primer specificity and sequence analysis}

For exact length verification, RT-PCR products were separated on 4\% high resolution gel electrophoresis. Amplified gradient MasterCycler (Eppenford) and LightCycler PCR products showed a single band and the expected length of $234 \mathrm{bp}$ for ER $\alpha, 262 \mathrm{bp}$ for ER $\beta$, $227 \mathrm{bp}$ for PR and a triple band of $198 \mathrm{bp}, 426 \mathrm{bp}$ and $654 \mathrm{bp}$ for poly-ubiquitin. Specificity of the desired products was additionally documented with melting curve analysis of LightCycler software 3.39 (Roche). Melting temperature of the high specific products are species and receptor subtype dependent between 83 and $83.3{ }^{\circ} \mathrm{C}$ for PR, 85.0 and $86.0^{\circ} \mathrm{C}$ for $\mathrm{ER} \alpha, 88.8$ and $89.3^{\circ} \mathrm{C}$ for $\mathrm{ER} \beta$ and 87.6 and $88.3^{\circ} \mathrm{C}$ for ubiquitin (UBQ). Sequence analysis (MWG Biotech, Ebersberg, Germany) of cloned RT-PCR products from Bos taurus showed 100\% homology with the published sequences (Pfaffl et al. 2002).

\section{Optimisation of specific RT-PCR}

Conditions for RT-PCRs were optimised in a gradient cycler with regard to Taq DNA polymerase (Roche), PCR water, $\mathrm{pH}$, primers (MWG), $\mathrm{MgCl}_{2}$ (Roche) concentrations and various annealing temperatures. Amplification products were separated on a $4 \%$ high resolution NuSieve agarose (FMC Bio Products, Rockland, MD, USA) gel electrophoresis and analysed with the Image Master system (Pharmacia). Optimised results were transferred on the following LightCycler PCR protocol.

\section{LightCycler PCR}

For the LightCycler reactions, a master mix of the following reaction components was prepared to the indicated end concentration: $6.4 \mu \mathrm{l}$ water, $1.2 \mu \mathrm{l} \mathrm{MgCl}_{2}$ $(4 \mathrm{mM}), 0 \cdot 2 \mu \mathrm{l}$ forward primer $(0 \cdot 2 \mu \mathrm{M}), 0 \cdot 2 \mu \mathrm{l}$ reverse primer $(0 \cdot 2 \mu \mathrm{M})$ and $1.0 \mu \mathrm{l}$ LightCycler DNA Master 


\section{a) $\operatorname{ER} \alpha$}

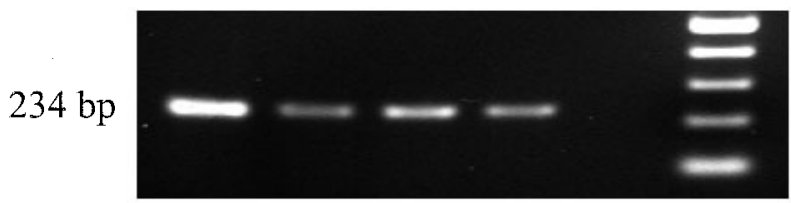

b) ERß

$262 \mathrm{bp}$

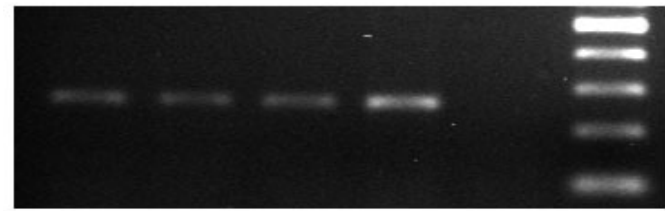

c) PR

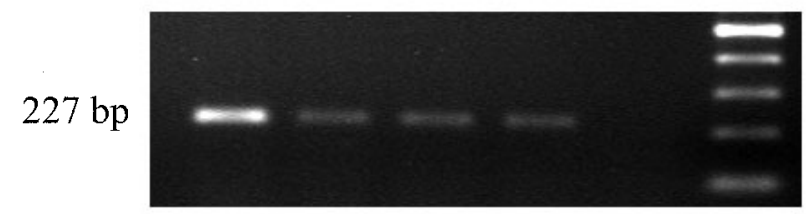

d) UBQ

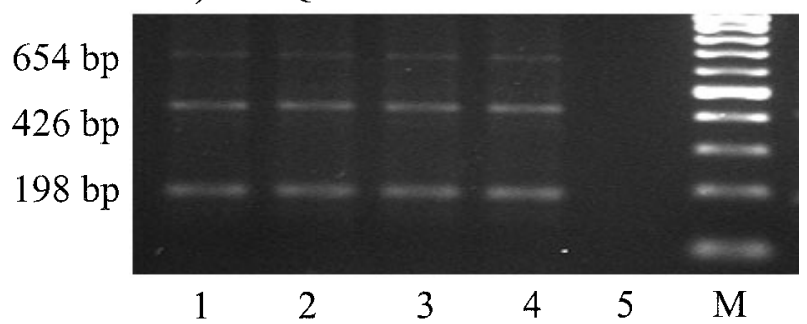

Figure 1 Representative samples of specific RT-PCR products for: (a) ER $\alpha$ (234 bp); (b) ER $\beta$ (262 bp); (c) PR (227 bp); (d) UBQ (198, $426,654 \mathrm{bp}$ ) in bovine mammary gland during different phases. Lane 1, non-pregnant heifers; lane 2, lactogenesis; lane 3, galactopoiesis; lane 4, involution; lane 5, no template control; lane M, DNA mass ladder (100-500 bp), separated by agarose gel electrophoresis.
SYBR Green I (Roche). Nine microlitres of LightCycler master mix was put in the LightCycler glass capillaries and $25 \mathrm{ng}$ reverse-transcribed total RNA in $1 \mu \mathrm{l}$ was added as a PCR template. The capillaries were closed, centrifuged in a micro-centrifuge and placed into the LightCycler rotor (Roche). To improve SYBR Green I quantification, a new 4th segment with a high temperature fluorescence acquisition point was included in the amplification cycle programme (Pfaffl 2001). The following LightCycler protocol was used for ER $\alpha, E R \beta$ and PR real-time PCR: a denaturation programme $\left(95^{\circ} \mathrm{C}\right.$ for $\left.30 \mathrm{~s}\right)$, a four segment amplification and quantification programme repeated 50 times for $\mathrm{ER} \alpha\left(95^{\circ} \mathrm{C}\right.$ for $3 \mathrm{~s} ; 64^{\circ} \mathrm{C}$ for $10 \mathrm{~s} ; 72{ }^{\circ} \mathrm{C}$ for $20 \mathrm{~s} ; 82^{\circ} \mathrm{C}$ for $3 \mathrm{~s}$ with a single fluorescence acquisition point), for $\operatorname{ER} \beta\left(95{ }^{\circ} \mathrm{C}\right.$ for $3 \mathrm{~s} ; 64{ }^{\circ} \mathrm{C}$ for $10 \mathrm{~s} ; 72{ }^{\circ} \mathrm{C}$ for $20 \mathrm{~s} ; 87^{\circ} \mathrm{C}$ for $3 \mathrm{~s}$ with a single fluorescence acquisition point), and for $\mathrm{PR}\left(95^{\circ} \mathrm{C}\right.$ for $3 \mathrm{~s} ; 65^{\circ} \mathrm{C}$ for $10 \mathrm{~s} ; 72{ }^{\circ} \mathrm{C}$ for $20 \mathrm{~s} ; 81^{\circ} \mathrm{C}$ for $3 \mathrm{~s}$ with a single fluorescence acquisition point), a melting curve programme $\left(60-95{ }^{\circ} \mathrm{C}\right.$ with a heating rate of $0 \cdot 1{ }^{\circ} \mathrm{C} / \mathrm{s}$ and a continuous fluorescence acquisition and finally a cooling programme down to $40{ }^{\circ} \mathrm{C}$.

\section{Housekeeping gene expression}

To confirm a constant housekeeping gene expression level in the investigated total RNA extractions, a UBQ realtime RT-PCR was performed. The primers (Table 1) were designed using a published bovine nucleic acidpoly-ubiquitin sequence (EMBL accession no. Z18245), and resulted in three RT-PCR products $198 \mathrm{bp}, 426 \mathrm{bp}$ and $654 \mathrm{bp}$ in length. Real-time RT-PCR was quantified in the LightCycler with the following UBQ specific settings $\left(95^{\circ} \mathrm{C}\right.$ for $3 \mathrm{~s} ; 64{ }^{\circ} \mathrm{C}$ for $10 \mathrm{~s} ; 72{ }^{\circ} \mathrm{C}$ for $20 \mathrm{~s} ; 85^{\circ} \mathrm{C}$ for $3 \mathrm{~s}$ with a single fluorescence acquisition point) as described above.

Table 3 Real-time RT-PCR mRNA expression of ER $\alpha$, ER $\beta$ and PR in bovine mammary gland tissue. Results (concentration of specific $\mathrm{mRNA} / \mu \mathrm{g}$ total RNA) represent means \pm S.E.M. from $n=4-6$ /group. (I) Non-pregnant heifers (18 months old); (II) lactogenesis (days 4-8 post partum); (III) galactopoiesis; (IIla) early (2-8 weeks); (IIIb) middle (4-5 months); (IIlc) late (8-12 months) and (IVa-e) involution (8 h, $24 \mathrm{~h}, 48 \mathrm{~h}, 96-108 \mathrm{~h}$ and $14-28$ days after the end of milking)

\begin{tabular}{|c|c|c|c|c|c|c|c|c|c|c|}
\hline & I & II & IIla & IIIb & IIIC & $\begin{array}{l}\text { IVa } \\
8 \mathrm{~h}\end{array}$ & $\begin{array}{l}\text { IVb } \\
24 \mathrm{~h}\end{array}$ & $\begin{array}{l}\text { IVc } \\
48 \mathrm{~h}\end{array}$ & $\begin{array}{l}\text { IVd } \\
96-108 \mathrm{~h}\end{array}$ & $\begin{array}{l}\text { IVe } \\
14-28 \text { days }\end{array}$ \\
\hline $\mathrm{ER} \alpha(\mathrm{fg} / \mu \mathrm{g})$ & $\begin{array}{c}284 \cdot 7^{a} \\
\pm 39 \cdot 1\end{array}$ & $\begin{array}{l}17 \cdot 2^{b} \\
\pm 5 \cdot 2\end{array}$ & $\begin{array}{l}25 \cdot 2^{b} \\
\pm 8 \cdot 6\end{array}$ & $\begin{array}{l}75 \cdot 3^{b} \\
\pm 13 \cdot 1\end{array}$ & $\begin{array}{l}129 \cdot 9^{b} \\
\pm 53 \cdot 8\end{array}$ & $\begin{array}{l}69 \cdot 1^{\mathrm{b}} \\
\pm 18 \cdot 1\end{array}$ & $\begin{array}{l}126 \cdot 1^{b} \\
\pm 17 \cdot 7\end{array}$ & $\begin{array}{l}49 \cdot 7^{b} \\
\pm 14 \cdot 7\end{array}$ & $\begin{array}{l}31 \cdot 2^{b} \\
\pm 10 \cdot 2\end{array}$ & $\begin{array}{l}69 \cdot 1^{b} \\
\pm 13 \cdot 8\end{array}$ \\
\hline $\mathrm{ER} \beta(\mathrm{ag} / \mu \mathrm{g})$ & $\begin{array}{l}200 \cdot 9^{b} \\
\pm 61 \cdot 3\end{array}$ & $\begin{array}{l}83 \cdot 0^{b} \\
\pm 44 \cdot 3\end{array}$ & $\begin{array}{l}156 \cdot 9^{b} \\
\pm 71 \cdot 2\end{array}$ & $\begin{array}{l}197 \cdot 1^{b} \\
\pm 56 \cdot 7\end{array}$ & $\begin{array}{l}93 \cdot 0^{b} \\
\pm 42 \cdot 8\end{array}$ & $\begin{array}{l}101 \cdot 4^{b} \\
\pm 18 \cdot 9\end{array}$ & $\begin{array}{l}54 \cdot 9^{b} \\
\pm 16 \cdot 3\end{array}$ & $\begin{array}{l}87 \cdot 3^{b} \\
\pm 15 \cdot 5\end{array}$ & $\begin{array}{l}93 \cdot 3^{b} \\
\pm 10 \cdot 2\end{array}$ & $\begin{array}{l}515 \cdot 2^{\mathrm{a}} \\
\pm 91 \cdot 7\end{array}$ \\
\hline $\mathrm{PR}(\mathrm{fg} / \mu \mathrm{g})$ & $\begin{array}{l}62 \cdot 5^{\mathrm{a}} \\
\pm 12 \cdot 7\end{array}$ & $\begin{array}{l}6 \cdot 7^{\mathrm{b}} \\
\pm 0 \cdot 7\end{array}$ & $\begin{array}{l}6 \cdot 2^{\mathrm{b}} \\
\pm 1 \cdot 2\end{array}$ & $\begin{array}{l}8 \cdot 2^{b} \\
\pm 1 \cdot 4\end{array}$ & $\begin{array}{l}9 \cdot 4^{b} \\
\pm 2 \cdot 7\end{array}$ & $\begin{array}{l}3 \cdot 9^{\mathrm{b}} \\
\pm 1 \cdot 3\end{array}$ & $\begin{array}{l}4 \cdot 4^{\mathrm{b}} \\
\pm 1 \cdot 0\end{array}$ & $\begin{array}{l}3 \cdot 9^{\mathrm{b}} \\
\pm 0 \cdot 7\end{array}$ & $\begin{array}{l}2 \cdot 4^{\mathrm{b}} \\
\pm 0 \cdot 9\end{array}$ & $\begin{array}{l}3 \cdot 0^{\mathrm{b}} \\
\pm 0 \cdot 6\end{array}$ \\
\hline
\end{tabular}


(a)

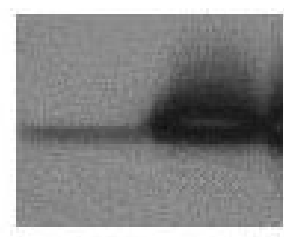

12

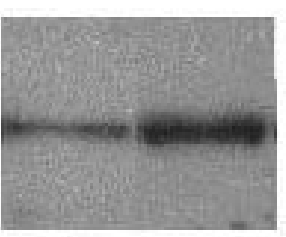

34

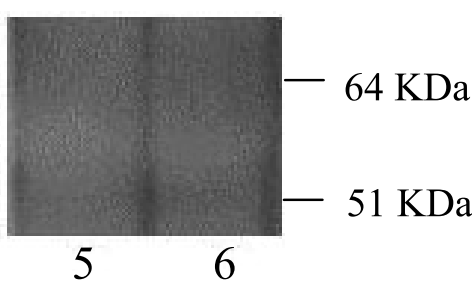

$5 \quad 6$

(b)

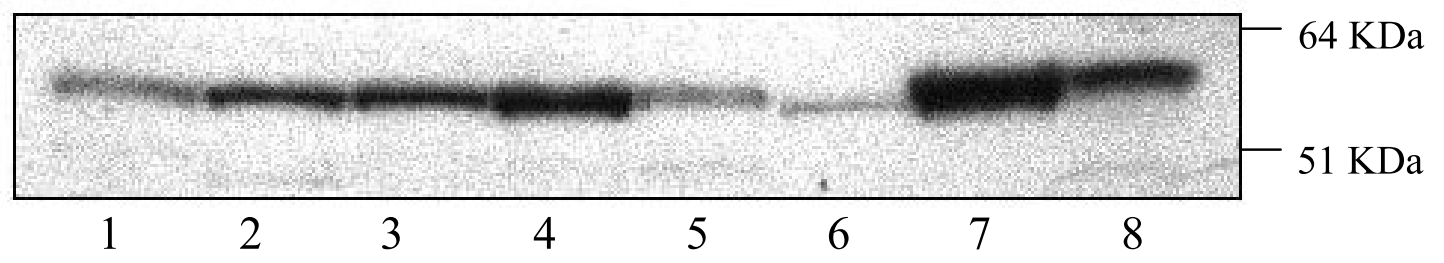

(c)

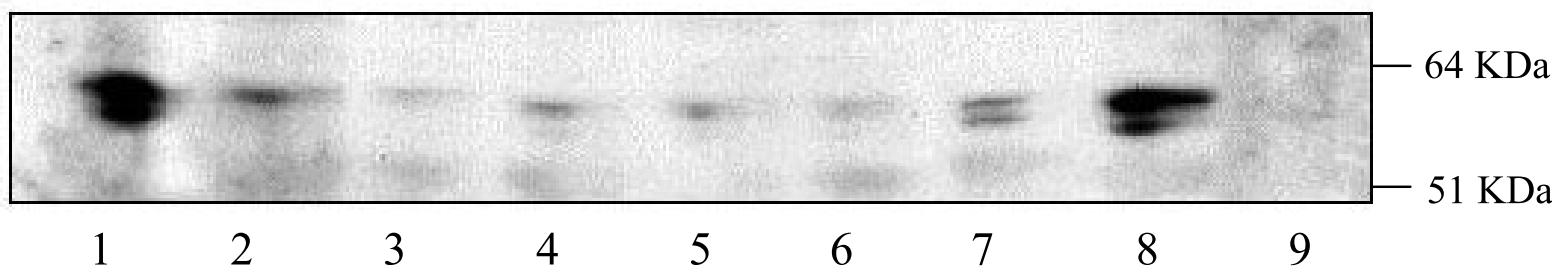

Figure 2 Western blot analysis of ER $\alpha$ in bovine mammary tissue. (a) Lanes 1 and 2, ER $\alpha$ protein ( 5 and 30 ng); lanes 3 and 4, $50 \mu \mathrm{g}$ tissue extract of mammary and endometrium tissue; lanes 5 and 6, mammary gland and endometrium, blocking of antibody with ER $\alpha$ protein. (b) Bovine mammary tissue extracts (50 $\mu$ g protein). Lane 1, non-pregnant heifers; lane 2, lactogenesis; lane 3, galactopoiesis; lanes 4 and 5, involution after $48 \mathrm{~h}$ or 4 weeks after the end of of milking; lane 6, corpus luteum at days 3-7; lane 7, endometrium; lane 8, cell lysate of MCF 7 cells. (c) Western blot analysis of ER $\beta$ in bovine mammary tissue. Lane 1, non-pregnant heifers; lane 2, lactogenesis; lanes 3, 4 and 5, early, middle and late galactopoiesis; lanes 6 and 7, involution 48 h or 4 weeks after the end of milking; lane 8 , endometrium tissue (positive control); lane 9, ER $\alpha$ protein (30 ng). The position of molecular weight markers is indicated on the right.

\section{Calibration curves}

For all quantitative assays an external calibration curve was used, based on a single stranded DNA (ssDNA) molecule calculation. ER $\alpha, E R \beta$ and PR RT-PCR products from
Bos taurus were cloned separately in pCR4.0 (Invitrogen, Leek, The Netherlands), linearised by a unique restriction digest and dilutions of each plasmid preparations from single copy ssDNA ( $<10$ molecules) up to $10^{10}$ ssDNA molecules were used in calibration curves (Pfaffl et al. 2001).

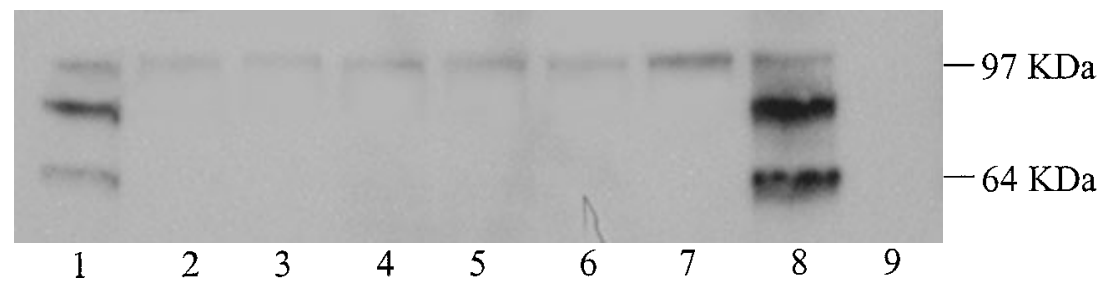

Figure 3 Western blot analysis of PR in bovine mammary tissue. Lane 1, non-pregnant heifers; lane 2, lactogenesis; lanes 3, 4 and 5, galactopoiesis during early, middle and late stages; lanes 6 and 7 , involution $48 \mathrm{~h}$ and 4 weeks after the end of milking; lane 8 , endometrium (positive control); lane 9, ER $\alpha$ protein (30 ng). The position of molecular weight markers is indicated on the right. 

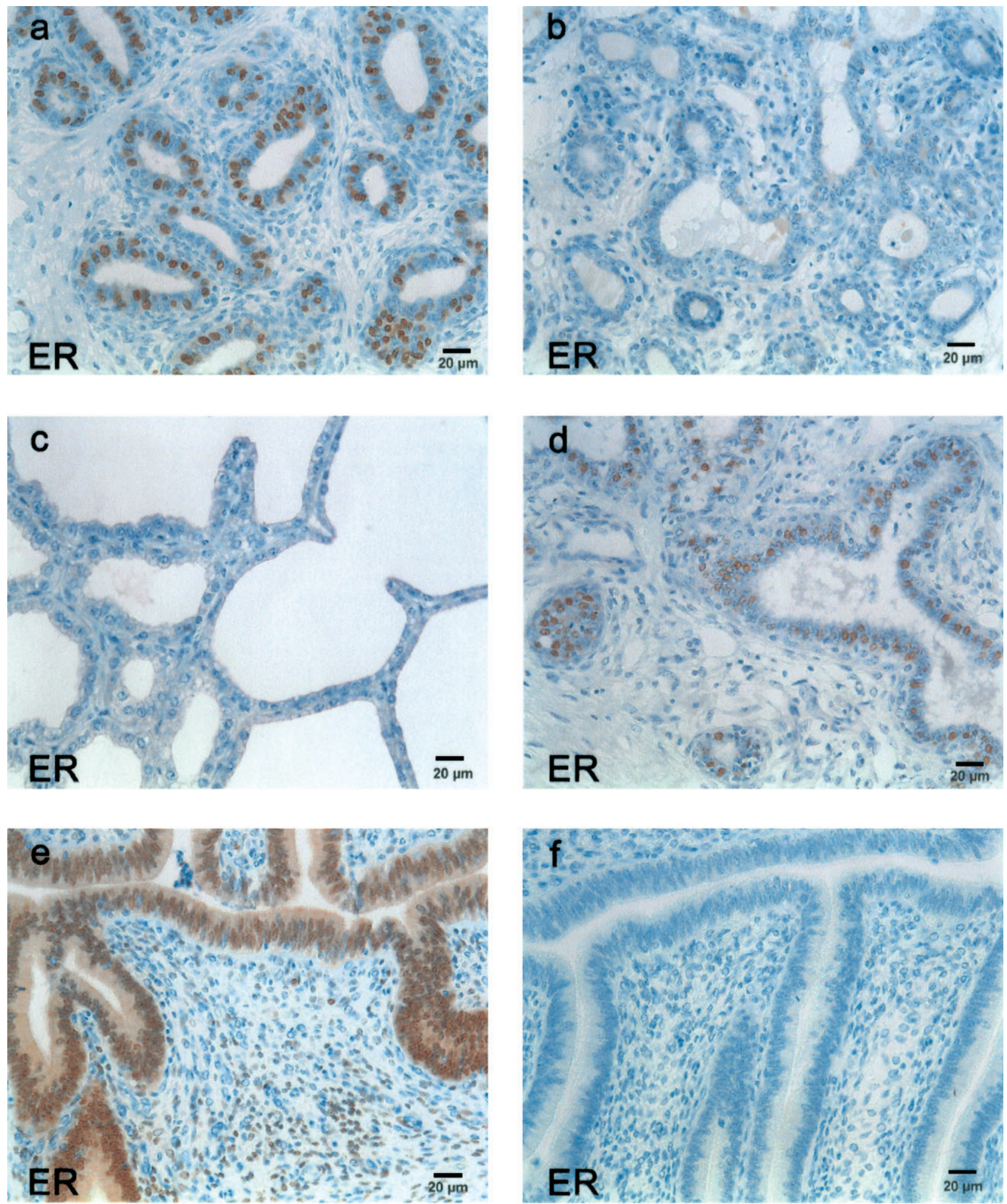

Figure 4 Immunohistochemical demonstration of ER $\alpha$ in bovine mammary gland. (a) Non-pregnant heifers; (b) first pregnancy (days 194-213); (c) lactogenesis/galactopoiesis; (d) involution (3-4 weeks); (e) endometrium tissue (positive control); (f) endometrium tissue (negative control). 


\section{Statistical analyses}

The statistical significance of differences in mRNA expression of examined factors was assessed by ANOVA, followed by the Bonferroni test. All experimental data are shown as the means \pm S.E.M.

\section{Results}

\section{Real-time RT-PCR assay validation}

All real-time assays performed were product specific, and an effective PCR amplification kinetic was shown by high PCR efficiency (Table 2). Assay sensitivities were confirmed by detection limits down $<30$ ag (14 ssDNA molecules) and linear quantification ranged over seven orders of magnitude (ag-ng range). Intra- and interassay variations of $<19 \%$ to $<30 \%$ respectively were determined over the entire quantification range (Pfaffl et al. 2003). The advantage of a high temperature fluorescence acquisition in the 4th segment during the amplification programme results in reliable and sensitive ER subtype-specific quantification with high linearity (Pearson correlation coefficient; $r>0.995$ ) over seven orders of magnitude. High temperature fluorescence acquisition melts the unspecific PCR products at $81{ }^{\circ} \mathrm{C}, 82^{\circ} \mathrm{C}, 87^{\circ} \mathrm{C}$ and $85^{\circ} \mathrm{C}$ respectively, eliminates the non-specific fluorescence signal derived from primer dimers and ensures an accurate quantification of the desired products (Fig. 1).

\section{Housekeeping gene expression}

UBQ mRNA expression levels were quantified in all samples $(n=53)$ and resulted in constant expression levels. No significant differences between the treatment groups could be shown in the investigated bovine mammary tissue. Expression of ER isoforms and PR mRNA were normalised according to the relative UBQ mRNA expression of each sample.

\section{Normalised tissue-specific ERa, ER $\beta$ and $P R$ expression}

The quantitative mRNA expression of the steroid hormone receptors ER $\alpha, E R \beta$ and PR in the bovine mammary gland at different stages of development and function are shown in Table 3. In general, the highest mRNA expression for $\mathrm{ER} \alpha$ and $\mathrm{PR}$ in $\mathrm{fg} / \mu \mathrm{g}$ total RNA range was found during early mammogenesis in non-pregnant heifers followed by a significant decrease to lower levels at the time of lactogenesis with low concentrations remaining during lactation and the first 4 weeks of involution. In contrast, expression of ER $\beta$ was about 1000-fold lower (ag/ $\mu \mathrm{g}$ range) and showed no clear difference during the stages examined, followed by a significant increase during 2-4 weeks of involution.

\section{Western blot}

The results of Western immunoblot for ER $\alpha$ are shown in Fig. $2 \mathrm{a}$ and $\mathrm{b}$ and for ER $\beta$ in Fig. 2c. In Fig. 2a lanes 1 and 2 , a clear dose-dependent (5 and $30 \mathrm{ng}$ ER $\alpha$ protein) band at $60 \mathrm{kDa}$ was visible and agrees with a similar band in mammary tissue (lane 3) and positive control (endometrium, lane 4). Both bands disappeared after blocking the antibody with ER $\alpha$ protein (lanes 5 and 6). The relative expression of $\mathrm{ER} \alpha$ protein in mammary tissue and control tissues (corpus luteum and endometrium) is demonstrated in Fig. $2 b$. The ER $\alpha$ protein was found in all mammary gland stages examined and in control tissues. The strongest signal was seen in endometrium (lane 7). The protein signal in non-pregnant heifers (lane 1) and 4-week involution (lane 5) was weaker compared with the other stages. Both ER $\alpha$ antibodies used (immunohistochemistry and Western blotting) seemed to be specific for ER and did not cross-react with the PR (no bands were visible around $116 \mathrm{kDa}$ (B isoform) and $92 \mathrm{kDa}$ (A isoform). As shown in Fig. 2c, a stronger signal (two bands at 62 and $58 \mathrm{kDa}$ ) was found for the ER $\beta$ protein in tissue extract of non-pregnant heifers (lane 1) and endometrium (lane 8, positive control) and 4 weeks after the end of milking (lane 7). In contrast, the signal during lactogenesis (lane 2), early, middle and late galactopoiesis (lanes 3, 4 and 5) and 2 days after the end of milking was very weak and represented only the $62 \mathrm{kDa}$ band. No signal and therefore no cross-reaction of the antibody was found with 30 ng ER $\alpha$ protein (lane 9).

The protein expression for the PR in mammary tissue, endometrium control tissue and possible cross-reaction with ER $\alpha$ protein is shown in Fig. 3. In lane 1 (nonpregnant heifers) and lane 8 (endometrium), three bands were visible corresponding to 116,92 and $65 \mathrm{kDa}$. In contrast, in lanes 2-7 (corresponding to the stage of lactogenesis, galactopoiesis and involution) only one band at $116 \mathrm{kDa}$ (isoform $\mathrm{B}$ ) was detectable. No cross-reaction with $\operatorname{ER} \alpha$ protein (lane 9) was visible.

\section{Immunohistochemistry}

Immunolocalisation for the ER $\alpha$ revealed a strong positive staining in most of the epithelial cells and occasionally in some fibroblasts of mammary glands of non-pregnant heifers (Fig. 4a). Myoepithelial cells, lipocytes and cells of the vascular system (endothelial cells, pericytes and smooth muscle cells) were consistently negative. As shown in Fig. $4 \mathrm{a}$, the intense staining for ER $\alpha$ was thereby clearly localised to the nucleus. During pregnancy (Fig. 4b, days 194-272) no immunoreaction for ER $\alpha$ could be detected in the cells of mammary tissue. The same was true for tissue probes taken during lactogenesis (Fig. 4c) and during all stages of galactopoiesis with the exception that in some sections occasionally single nuclei of epithelial cells were labelled with the antibody against ER $\alpha$. 
In contrast to the beginning of involution (3-4 weeks after the end of milking), again a distinct and selective staining for the receptor could be demonstrated for the first time in the nuclei of mammary epithelial cells (Fig. $4 d)$. This staining pattern continued up to 2.5 years. The intensity of the staining and the number of positive cells were reduced if compared with mammary tissue of non-pregnant heifers (Fig. 4a).

Contrary to the expression of ER $\alpha$ the pattern of PR localisation differed in the tissue investigated. The PR was localised in the nuclei of epithelial cells in the mammary tissue of heifers (Fig. 5a) in a manner comparable with that described for ER $\alpha$ expression with the exception that some stromal and vascular cells were also positive stained. In primigravid animals, the PR was predominantly strongly expressed in the nuclei of basal localised epithelial cells (Fig. 5b). During lactogenesis (Fig. 5c), preferentially groups of epithelial nuclei were positive. Additionally, an increased staining of cytoplasm of epithelial cells was obvious. The staining intensity and localisation were similar during peak and mid lactation followed by a change during late lactation and involution where staining was now observed again in the nuclei of epithelial cells (Fig. 5d). Besides the epithelial cells, a strong and pronounced staining of stromal cells and vascular cells could also be observed (Fig. 5b, c and d). A negative control (replacing of the primary antibody with non-immune serum) is shown in Fig. 5e and showed no background staining.

\section{Discussion}

Our mRNA expression results have demonstrated a relatively high mRNA expression of ER $\alpha$ and PR in the mammary tissue of non-pregnant heifers in the range of $\mathrm{fg} / \mu \mathrm{g}$ total RNA. This high level was down-regulated with the beginning of the lactation period (lactogenesis and galactopoiesis), and may be caused by constantly high levels of progesterone and increasing levels of oestradiol (Theyerl-Abele et al. 1990) during the second half of pregnancy. The mRNA data were confirmed by demonstration of the protein for ER $\alpha$ and PR by immunohistochemistry with strong signals of staining of epithelial cell nuclei. During lobulo-alveolar development (the second half of pregnancy) the positive staining for ER $\alpha$ had already disappeared, suggesting decreased production of protein and it may also indicate reduced expression of mRNA as measured later during lactogenesis. This was not confirmed by the Western blot data. The high mRNA expression in non-pregnant heifers was not clearly reflected by protein detected in Western blot. In contrast, higher protein expression by Western blot during lactogenesis, galactopoiesis and early involution did not correlate with immunohistochemistry and mRNA expression. One of the main reasons for the discrepancies could be the difference in the sensitivity of the different techniques used. The LightCycler technology is very sensitive with high variations. In contrast, immunohistochemistry and Western blot depend on the antibody used and are relatively insensitive. Another possibility could be different half-lives for mRNA and protein during the different stages examined. The Western blot band for ER $\alpha$ $(60 \mathrm{kDa})$ in bovine mammary tissue agrees with observations in other species and disappeared after the antibody was blocked with the $\mathrm{ER} \alpha$ protein.

The expression of PR mRNA, protein localisation and Western blot band intensities agrees better if compared with ER $\alpha$. By Western blot three bands were found of $\mathrm{kDa} 116$ (B isoform), 92 (A isoform) and $65 \mathrm{kDa}$ (C isoform) which have not yet been demonstrated for the bovine species, but are in agreement with observations in other species such as rat (Ogle 2002, Le Mellay \& Lieberherr 2000), human (Wei et al. 1997, Vienonen et al. 2002) and monkey (Haluska et al. 2002). All three isoforms were only found in the mammary gland of non-pregnant heifers and endometrium (positive control) but not in the mammary tissue at other stages. The ratio between isoform $\mathrm{A}$ to $\mathrm{B}$ in non-pregnant heifers is about 3:1 and agrees with observations reported for the murine species (Schneider et al. 1991). The high mRNA expression in non-pregnant heifers agrees therefore with the higher protein content. During the other stages examined, only the $\mathrm{B}$ isoform was detected with a stronger band during involution (4 weeks after the end of milking). The antibody used for PR showed no cross-reaction with the $\mathrm{ER} \alpha$ protein and gave staining signals during all stages examined. The distinct staining of PR in the nuclei of epithelial cells of mammary ducts (non-pregnant heifers) may reflect predominant staining with the $\mathrm{A}$ isoform. This isoform was, for example, predominantly found in the nuclear fraction after rat decidua homogenisation (Ogle 2002). The more intensive staining of cytoplasm during lactogenesis and lactation may indicate reaction with the $\mathrm{B}$ isoform. This again agrees with observations in the rat decidua homogenisation experiment and predominant localisation in the cytosolic fraction (Ogle 2002). The changes in isoforms in the bovine mammary gland may also indicate possible changes in biological function. In vitro studies have shown that the $\mathrm{A}$ and $\mathrm{B}$ forms can have different functions in the same cell and also that the activity of the individual form of the receptors can vary among different cell types (Vegeto et al. 1993). For example, in human endometrium, both the absolute levels of $\mathrm{PR}$ and the ratios of the $\mathrm{A}$ and $\mathrm{B}$ proteins vary dramatically throughout the menstrual cycle (Mangal et al. 1997). Human PR-A functions as a transcriptional inhibitor of all steroid hormone receptors and a facilitator of ligand-dependent cross-talk among signalling pathways of sex steroid receptors within the cell. Human PR-B appears to be the transcriptional activator of progesteroneresponsive genes. Thus, the ratio of $\mathrm{hPR}-\mathrm{A}$ and $\mathrm{hPR}-\mathrm{B}$ in 

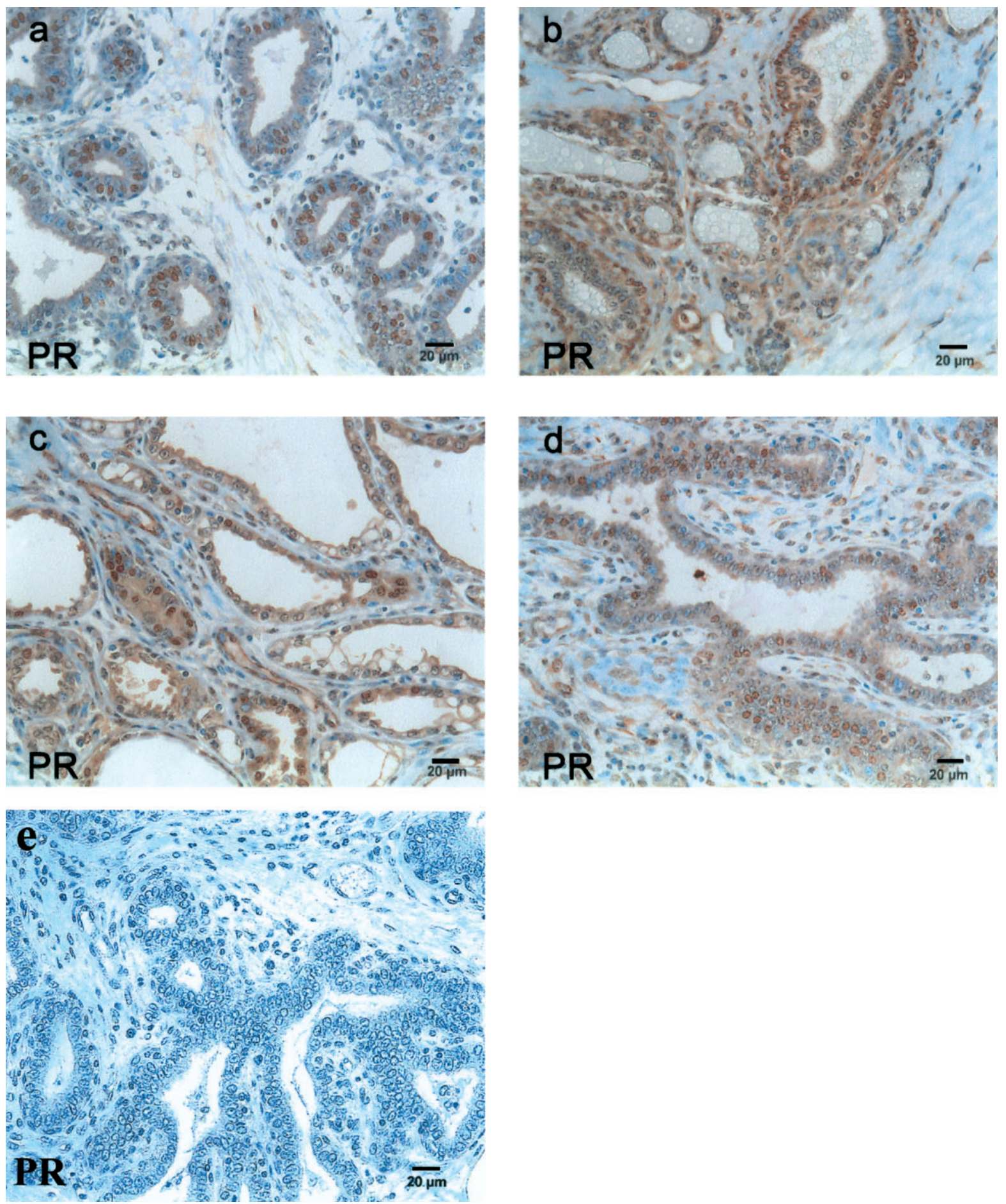

Figure 5 Distribution of PR in bovine mammary tissue by immunohistochemistry. PR was immunolocalised in the nuclei of gland cells, cells of the vascular system and in stromal cells. Strong staining of epithelial cells is observed in: (a) non-pregnant heifers; (b) primigravid animals (194 days of pregnancy); (c) lactation (13 months of lactation); (d) involution (3-4 weeks after the end of milking); (e) negative control when the primary PR antibody was replaced by non-immune serum. 
specific cell types defines the physiologic and pharmacologic response to progesterone (Wen et al. 1994). Not very much is known about the PR-C form. In the rat, PR-C is predominantly cytosolically located after tissue homogenisation and has no transcriptional activity by itself and may render the transcriptional capabilities of PR-A and PR-B less efficient (Ogle 2002).

The ER $\beta$ mRNA expression was, in general, 1000-fold lower expressed (ag/ $\mu$ g total RNA) compared with ER $\alpha$, did not show such a significant decrease during mammogenesis and remained at this low level during lactogenesis and galactopoiesis. In general, the trend of $\operatorname{ER} \beta$ mRNA expression was confirmed by the Western blot data with two isoforms at 62 and $58 \mathrm{kDa}$ and stronger signals in non-pregnant heifers and 4 weeks after the end of milking (involution); during lactogenesis and galactopoiesis only a weak signal representing the $62 \mathrm{kDa}$ isoform was detectable. In general, the two isoforms of $\operatorname{ER} \beta$ agree with Western blot data from human reproductive tissues (Choi et al. 2001). Our results in the cow are in contrast to rat mammary gland with low levels of mRNA for ER $\alpha$ and ER $\beta$ in the glands of virgin and pregnant animals, followed by a clear up-regulation during lactation and decrease again during post lactation. The ER $\beta$ protein was more abundantly expressed than $\operatorname{ER} \alpha$ protein in the rat mammary gland. At every developmental stage, the ER $\beta$ content of the mammary gland was higher than that of ER $\alpha$. Maximum expression of ER in rat (mRNA and protein) has been found during lactation (Saji et al. 2001). The ER $\beta$ appears to be expressed in more cells than ER $\alpha$ in rats and mice (Zeps et al. 1999, Saji et al. 2000). Furthermore, in human breast samples, ER $\beta$ mRNA and protein (immunohistochemistry) were more frequently detected in epithelial cells of normal mammary gland than ER $\alpha$ (Speirs et al. 2000). There are indications in the rat mammary gland for ER $\beta$ to be a negative regulator of $\operatorname{ER} \alpha$. One of the conditions to support the hypothesis is co-localisation of ER $\beta$ with ER $\alpha$ in the same nuclei. In pregnant mammary gland about $70 \%$ of $E R \alpha$ is expressed alone and is free from potential inhibition by ER $\beta$. However, during the lactation period, co-localisation of ER $\beta$ with ER $\alpha$ is increased, and in $70-80 \%$ of ER $\alpha$ containing cells ER $\alpha$ may be antagonised by $\operatorname{ER} \beta$ (Saji et al. 2001). The results in the cow suggest that $\operatorname{ER} \beta$ may have little importance for the development and function of the mammary gland. Due to the very low mRNA expression of $E R \beta$, inhibiting effects on $E R \alpha$ expression and function cannot be excluded but seem to be rather unlikely. In contrast, ER $\alpha$ and PR may play an important role for mammogenesis as assumed from in vivo experiments in cattle and sheep by artificial induction of lactation with the ligands in non-pregnant animals (Erb 1977). Induction of lobulo-alveolar development can only be induced without inhibition of prolactin (Schams 1976, Schams et al. 1984). Treatment of juvenile sheep with oestrogen plus progesterone increased the percentage of alveole areas from $0 \cdot 1 \%$ (control) to $52 \%$ and after prolactin inhibition by bromocriptine to only $3 \cdot 1 \%$. Treatment with progesterone alone showed no clear effect (2.7\%) (Schams et al. 1984). These results demonstrate the importance of oestrogen or oestrogen plus progesterone as a competence factor for the action of prolactin. Progesterone seems only to act together with oestrogen or, if at all, to induce lobulo-alveolar development in ruminants. In contrast, it is now well established that oestrogen and progesterone are absolutely essential for mammary epithelial cell proliferation and differentiation in mice. In the mammary glands of mice, the synthesis of $\mathrm{PR}$ is under oestrogenic regulation and progesterone, in turn, can antagonise oestrogen action, thereby down-regulating its own receptor (Shyamala \& Haslam 1980).

More information about the relative roles of ER and PR in mammary development are obtained from $\mathrm{KO}$ mice. In ERKO mice, ductal morphogenesis is markedly impaired (Bocchinfuso \& Korach 1997). On the other hand, ductal growth is unimpaired in mammary glands of PRKO mice (Shyamala 1999). The mammary glands of PRKO mice, however, fail to undergo lobulo-alveolar growth (Lydon et al. 1995). An important distinction between the actions of oestrogen and progesterone on mammary development emerges from the observations of ERKO and PRKO mice. While both oestrogen and progesterone can promote epithelial cell proliferation, only progesterone and PRdependent proliferation are coupled to differentiation (Shyamala et al. 1999). According to different mRNA expression patterns and intensity of staining for ER and PR in cow mammary tissue (especially earlier downregulation during cow mammary gland development), differences in signalling pattern are assumed if compared with rodents.

The presence of high ER $\alpha, E R \beta$ and PR levels before the start of lobulo-alveolar development and significantly lower levels during pregnancy and lactogenesis suggests an important functional role for the initiation of lobuloalveolar development possible in co-operation with proliferative acting growth factors. The mRNA expression pattern of some proliferative growth factors in cow mammary gland during development and function shows a comparable picture with $\mathrm{ER} \alpha$ and $\mathrm{PR}$ expression. The highest expression levels were detected for transforming growth factor- $\alpha$, fibroblast growth factor 2 and insulin-like growth factor-I in non-pregnant heifers with a decreasing tendency during pregnancy and relative low levels during lactogenesis and lactation followed by an up-regulation during involution (Plath et al. 1997, 1998, Plath-Gabler et al. 2001).

Our results concerning the localisation of $\mathrm{PR}$ in the nuclei of epithelial cells of mammary ducts agree with observations in the mouse. PR were also absent from the fatty stroma surrounding the epithelial cells (Silberstein et al. 1996). The decreased staining of PR in nuclei of 
epithelial cells and more intensive staining of cytoplasm during lactation may indicate a possible shift in $\mathrm{PR}$ isoform production (as shown by Western blot) or in PR function. The still positive staining for PR in cow mammary tissue during pregnancy, lactogenesis and galactopoiesis looks to be in contrast to the significant decrease of mRNA expression. Several reasons for the different regulatory pattern are possible: (i) change in half-life for PR mRNA, (ii) improvement of translational activity and (iii) dilution effect of mRNA due to the over-expression of mRNA for milk proteins. However, our PR mRNA data agree to some extent with observations in mouse mammary gland. PR mRNA was detected in tissues from nulliparous mice which decreased dramatically during pregnancy, became undetectable during lactation, and were once again detectable in glands from mice undergoing lactational involution (Shyamala et al. 1990). The concentration of PR in gilt mammary gland was high at the onset of pregnancy and declined after 75 days until parturition, and the receptors were not identifiable at day 21 of lactation (Lin \& Buttle 1991).

The demonstration of positive staining for ER $\alpha$ 2-4 weeks after the end of lactation seems not to be reflected by mRNA expression, but agrees better with the Western blot data. The reason is not known but could be due to a change in translation or protein degradation activity. There are no data available for the involution period after the end of lactation in pregnant animals. The increase of $\mathrm{ER} \alpha$ at $2-4$ weeks of involution can be interpreted as preparation of tissue for new mammogenic activity if specific signals are released. The significant up-regulation of ER $\beta$ 2-4 weeks after the end of lactation may be interpreted in a way similar to that for the ER $\alpha$. As shown in rat mammary gland in the presence of oestradiol-17 $\beta$, $\mathrm{ER} \alpha$ is an activator, but $\mathrm{ER} \beta$ is an inhibitor or silencer, at activating protein-1 sites (Paech et al. 1997). Therefore, more research is needed in this area, especially in pregnant animals.

In conclusion, the mRNA expression and protein data for ERs and PR show clear regulatory changes suggesting involvement of these receptors in cow mammary gland development and involution.

\section{Acknowledgements}

We should like to thank the Animal Experimental Station Thalhausen (Dr H R Fries and Dr H Eichinger) for the generous support with dairy cows for the experiments and the German Research Foundation (DFG, Scha 257/13) for support. The expert technical assistance of Mrs M Partsch is also highly appreciated.

\section{References}

Bocchinfuso WP \& Korach KS 1997 Mammary gland development and tumorgenesis in estrogen receptor knockout mice. Journal of Mammary Gland Biology and Neoplasia 2 323-334.
Choi I, Ko C, Park-Sarge O-K, Nie R, Hess RA, Graves C \& Katzenellenbogen BS 2001 Human estrogen receptor beta-specific monoclonal antibodies: characterization and use in studies of estrogen receptor beta protein expression in reproductive tissues. Molecular and Cellular Endocrinology 181 139-150.

Collier RJ, McGrath MF, Byatt JC \& Zurfluh LL 1993 Regulations of bovine mammary gland growth by peptide hormones: involvement of receptors, growth factors and binding proteins. Livestock Production Science 35 211-233.

Conneely OM, Lydon JP, De Mayo F \& O’Malley BW 2000 Reproductive functions of the progesterone receptor. Journal of the Society for Gynecologic Investigation 7 (Suppl 1) S25-S32.

Cowie AT, Forsyth IA \& Hart IC 1980 Hormonal control of lactation. In Monographs on Endocrinology, vol. 15. Eds F Gross, MM Grumbach, A Labhardt et al. Berlin, Heidelberg, New York: Springer Verlag.

Daniel CW \& Silberstein GB 1987 Postnatal development of the rodent mammary gland. In The Mammary Gland: Development, Regulation and Function, pp 3-36. Eds MC Neville \& CW Daniel. New York: Plenum Press.

Erb RE 1977 Hormonal control of mammogenesis and onset of lactation in cows - a review. Journal of Dairy Science 60 155-169.

Haluska GJ, Wells TR, Hirst JJ, Brenner RM, Sadowsky D \& Novy MJ 2002 Progesterone receptor localization and isoforms in myometrium, decidua, and fetal membranes from rhesus macaques: evidence for functional progesterone withdrawal at parturition. Journal of the Society for Gynecologic Investigation 9 125-136.

Hsu SM, Raine L \& Fanger H 1981 Use of avidin-biotin-peroxidase complex $(\mathrm{ABC})$ in immunoperoxidase techniques: a comparison between $\mathrm{ABC}$ and unlabeled antibody (PAP) procedures. Journal of Histochemistry and Cytochemistry 29 577-580.

Le Mellay V \& Lieberherr M 2000 Membrane signaling and progesterone in female and male osteoblasts. II. Direct involvement of G alpha q/11 coupled to PLC-beta 1 and PLC-beta 3. Journal of Cellular Biochemistry 79 173-181.

Lin CL \& Buttle HL 1991 Progesterone receptor in the mammary tissue of pregnant and lactating gilts and the effect of tamoxifen treatment during late gestation. Journal of Endocrinology $\mathbf{1 3 0}$ 251-257.

Lydon JP, DeMayo FJ, Funk CR, Mani SK, Hughes AR, Montgomery CA Jr, Shyamala G, Conneely OM \& O'Malley BW 1995 Mice lacking progesterone receptor exhibit pleiotropic reproductive abnormalities. Genes and Development 9 2266-2278.

Mangal RK, Wiehle RD, Poindexter AN III \& Weigel NL 1997 Differential expression of uterine progesterone receptor forms A and B during the menstrual cycle. Journal of Steroid Biochemistry and Molecular Biology 63 195-202.

Ogle TF 2002 Progesterone-action in the decidual mesometrium of pregnancy. Steroids 67 1-14.

Paech K, Webb P, Kuiper GG, Nilsson S, Gustafsson J, Kushner PJ \& Scanlan TS 1997 Differential ligand activation of estrogen receptors ER $\alpha$ and ER $\beta$ at AP1 sites. Science 277 1508-1510.

Peterson CM 2000 Estrogen and progesterone receptors: an overview from the year 2000. Journal of the Society for Gynecologic Investigation 7 (Suppl 1) S3-S7.

Pfaffl MW 2001 Development and validation of an externally standardised quantitative insulin like growth factor-1 (IGF-1) RT-PCR using Light-Cycler SYBR ${ }^{\oplus}$ Green technology. In Rapid Cycle Real-time PCR, Methods and Applications, pp 281-291. Eds S Meuer, C Wittwer \& K Nakagawara. Heidelberg: Springer Verlag.

Pfaffl MW, Lange IG, Daxenberger A \& Meyer HHD 2001 Tissue-specific expression pattern of estrogen receptors (ER): quantification of ER alpha and ER beta mRNA with real-time RT-PCR. Acta Pathologica Microbiologica et Immunologica Scandinavica 109 345-355.

Pfaffl MW, Daxenberger A, Hageleit M \& Meyer HHD 2002 Effects of synthetic progestagens on the mRNA expression of androgen 
receptor, progesterone receptor, estrogen receptor $\alpha$ and $\beta$, insulin-like growth factor (IGF)-1 and IGF-1 receptor in heifer tissues. Journal of Veterinary Medicine A 49 57-64.

Plath A, Einspanier R, Peters F, Sinowatz F \& Schams D 1997 Expression of transforming growth factors alpha and beta-1 messenger RNA in the bovine mammary gland during different stages of development and lactation. Journal of Endocrinology 155 501-511.

Plath A, Einspanier R, Gabler C, Peters F, Sinowatz F, Gospodarowicz D \& Schams D 1998 Expression and localization of members of the fibroblast growth factor family in the bovine mammary gland. Journal of Dairy Science 81 2604-2613.

Plath-Gabler A, Gabler C, Sinowatz F, Berisha B \& Schams D 2001 The expression of the IGF family and GH receptor in the bovine mammary gland. Journal of Endocrinology 168 39-48.

Rosenfeld CS, Yuan X, Manikkam M, Calder, MD, Garverick HA \& Lubahn DB 1999 Cloning, sequencing, and localization of bovine estrogen receptor- $\beta$ within the ovarian follicle. Biology of Reproduction 60 691-697.

Saji S, Jensen EV, Nilsson S, Rylander T, Warner M \& Gustafsson JA 2000 Estrogen receptors alpha and beta in the rodent mammary gland. PNAS 97 337-342.

Saji S, Sakaguchi H, Andersson S, Warner M \& Gustafsson JA 2001 Quantitative analysis of estrogen receptor proteins in rat mammary gland. Endocrinology 142 3177-3186.

Schams D 1976 Hormonal control of lactation. In Ciba Foundation Symposium 45, pp 27-48. North Holland, Amsterdam, Oxford, New York: Elsevier Excerpta Medica.

Schams D, Rüsse I, Schallenberger E, Prokopp S \& Chan JS 1984 The role of steroid hormones, prolactin and placental lactogen on mammary gland development in ewes and heifers. Journal of Endocrinology 102 121-130.

Schneider W, Ramachandran C, Satyaswaroop PG \& Shyamala G 1991 Murine progesterone receptor exists predominantly as the 83-kilodalton 'A' form. Journal of Steroid Biochemistry and Molecular Biology 38 285-291.

Schuler G, Wirth C, Teichmann U, Failing K, Leiser R, Thole H \& Hoffmann B 2002 Occurrence of estrogen receptor alpha in bovine placentomes throughout mid and late gestation and at parturition. Biology of Reproduction 66 976-982.

Shyamala G 1999 Progesterone signaling and mammary gland morphogenesis. Journal of Mammary Gland Biology and Neoplasia 4 89-104.

Shyamala G \& Haslam SZ 1980 Estrogen and progesterone receptors in normal mammary gland during different functional states. In Perspectives on Steroid Receptor Research, pp 193-216. Ed. F Bresciani. New York: Raven.
Shyamala G, Schneider W \& Schott D 1990 Developmental regulation of murine mammary progesterone receptor gene expression. Endocrinology 126 2882-2889.

Shyamala G, Louie SG, Camarillo IG \& Talamantes F 1999 The progesterone receptor and its isoforms in mammary development. Molecular Genetics and Metabolism 68 182-190.

Silberstein GB, Van Horn K, Shyamala G \& Daniel CW 1996 Progesterone receptors in the mouse mammary duct: distribution and developmental regulation. Cell Growth and Differentiation 7 945-952.

Speirs V, Adams IP, Walton DS \& Atkin SL 2000 Identification of wild-type and exon 5 deletion variants of estrogen receptor beta in normal human mammary gland. Journal of Clinical Endocrinology and Metabolism 85 1601-1605.

Theyerl-Abele M, Meyer HHD, Schams D \& Karg H 1990 Konzentration von IGF-I und Oestradiol-17 $\beta$ im Blutplasma des graviden Rindes. Deutsche Tierärztliche Wochenschrift 97 382-385.

Topper YJ \& Freeman CS 1980 Multiple hormone interactions in the developmental biology of the mammary gland. Physiological Reviews 60 1049-1106.

Vegeto E, Shahbaz MM, Wen DX, Goldman ME, O'Malley BW \& McDonnell DP 1993 Human progesterone receptor A form is a cell- and promoter-specific repressor of human progesterone receptor B function. Molecular Endocrinology 7 1244-1255.

Vienonen A, Syvala H, Miettinen S, Tuohimaa P \& Ylikomi T 2002 Expression of progesterone receptor isoforms A and B is differentially regulated by estrogen in different breast cancer cell lines. Journal of Steroid Biochemistry and Molecular Biology 80 307-313.

Wei LL, Norris BM \& Baker CJ 1997 An N-terminally truncated third progesterone receptor protein, $\mathrm{PR}(\mathrm{C})$, forms heterodimers with $\mathrm{PR}(\mathrm{B})$ but interferes in $\mathrm{PR}(\mathrm{B})-\mathrm{DNA}$ binding. Journal of Steroid Biochemistry and Molecular Biology 62 287-297.

Wen DX, Xu YF, Mais DE, Goldman ME \& McDonnell DP 1994 The $\mathrm{A}$ and $\mathrm{B}$ isoforms of the human progesterone receptor operate through distinct signaling pathways within target cells. Molecular and Cellular Biology 14 8356-8364.

Zeps N, Bentel JM, Papadimitriou JM \& Dawkins HJ 1999 Murine progesterone receptor expression in proliferating mammary epithelial cells during normal pubertal development and adult estrous cycle. Association with eralpha and erbeta status. Journal of Histochemistry and Cytochemistry 47 1323-1330.

Received in final form 21 January 2003

Accepted 28 January 2003 